\title{
INFLUENCE OF INFRASTRUCTURE DEVELOPMENT ON ECONOMIC GROWTH IN BRICS COUNTRIES
}

\author{
Bilal Hussain', Syed Asif Ali Naqvi ${ }^{2}$, Muhammad Sohail Amjad Makhdum³, Syed \\ Ale Raza Shah ${ }^{4}$ \\ ${ }^{1,4}$ Research Assistant, Department of Economics, Government College University Faisalabad, \\ Pakistan,E-mail: bilalhussain1410@gmail.com, syedaaleraza56@gmail.com \\ ${ }^{2}$ Assistant Professor, Department of Economics, Government College University Faisalabad, \\ Pakistan, Mobile: +923004691512,E-mail: syedasif_1@yahoo.com \\ ${ }^{3}$ Assistant Professor, Department of Economics, Government College University Faisalabad, \\ Pakistan, E-mail: sohailmakhdum@hotmail.com
}

Received 1403 2019; accepted 02092019

This paper quantified the impact of infrastructure on economic growth for the BRICS countries. Causal relationship between infrastructural development and economic growth was also analyzed. Two different models have been used for this purpose. For exigency regarding our objectives, data from 1981 -2016 years has been conjured up. Autoregressive Distributed Lag (ARDL) model was applied for the sake of analysis. The findings of study exhibited that transport, and telecommunication infrastructure brings about positive impact on economic growth as compare to energy infrastructure. It is necessary to devise policies that improve will improve physical as well as social infrastructure. In these new times where technology leads the way, special focus should be given to telecommunication infrastructure as the future will draw opulence in this sector.

Keywords: Economic growth; infrastructure; development; telecommunication.

JEL Codes: O00, P48, R11

\section{Introduction}

Improvement in fiscal, economic, and social conditions of nations over time is development (Berg, 2016). A nation's infrastructure development can contribute a noteworthy part in its economic growth (Peters 2008). Capital stock, labor inputs and innovations are some of many ways to weigh in economic growth (EG) of any nation. The association between infrastructure and EG has, in current years, become one of the significant economic subjects for both academic and policy circles (Bassanini et.al, 2000; Laursen, 2000; Smulders and Nooij, 2003; Wei, 2008; Narayan, 2013). The influence of an efficient and effective transportation system to EG and steadiness are frequent, for example, the costs of transportation and production are reduced through timely delivery and increasing the economies of scale in the production process, integrating markets, creating economic opportunities, and communication links,

Copyright (C) 2019 The Authors. Published by Vytautas Magnus University. This is an open-access article distributed under the terms of the Creative Commons Attribution-NonCommercial 4.0 (CC BY-NC 4.0) license, which permits unrestricted use, distribution, and reproduction in any medium, provided the original author and source are credited. The material cannot be used for commercial purposes. 
enhancing the competitive advantage of the production and economy, thereby promoting trade (Asteriou and Agiomirgianakis, 2001; Afzal et al. 2012; Castelló and Doménech, 2002; Fedderke and Garlick, 2008; Hye and Lau, 2015).EG and economic development are not same but two sides of a coin. Increasing trends in GDP and income per capita economic growth for nations (Rodriguez and Rodrik, 2000). An increase in the life expectancy as well as improvement in the literacy followed by the decimation of poverty can be put in the brackets of economic development (Porter, 2000). It will not be presumptuous if one can put about that economic growth cannot be achieved till economic development is not taken under account (Borhan and Ahmed, 2012; AlRawashdeh et.al, 2015; Zaman et.al, 2016). Rampant growth in economic growth may be procured given the proper triage to natural resources, physical capitals, curb of pollution within the premise. Hence this paper strives to make a point of economic growth in the BRICS countries where BRICS stands for the initials of the country names (Brazil, Russia, India, China and South Africa).

Development of any country stands on the infrastructure of a country which stirs the economic growth and brings in the money (Esfahani and Ramírez, 2003; Czernich et.al, 2011). The expedition towards developed from developing nations can only be ascertained by the infrastructure in the premise (Sridhar, 2008). Infrastructure has been bifurcated into two types tangible and intangible (Perez and Wilson, 2012). We put rail, airports, and roads in the hard infrastructure while education, health and many more is put in the soft infrastructure. Economy cannot work if deprived of either of the type of infrastructure.

They both bear different features, as hard infrastructure is tangible, while soft infrastructure is in tangible. According to some indexes Brazil stands 9th largest country when we compare the nominal GDP and on the front of purchasing power parity, it stands at 8th slot. Data from World Bank validates the economic growth of the country since they have means at their disposals to substantiate their claims. Brazil have more than 200 million populations and most of them live in the urban areas (Marcilio and Gouveia, 2007).

As time will go by with the increase in economic growth and development there will be a dire need to amplify the basic facilities. Infrastructure did and will always play a paramount role in the growth of economy. Infrastructure is just as important for urban areas as it is for rural areas. When we talk about Brazil, we witness a trend which is on hike as far as the infrastructure goes by (like, toll roads, airports, railways, ports etc.) which is being used for the betterment of the denizens of the country. Russia is the largest country in the world as far as the land goes. Thereof infrastructure in Russia does not render much because of the cold milieu which comes into play (Brown et.al, 2008; Coulibaly, 2013; Portugal-Perez \& Wilson 2012). Economic growth of Russia has also been jotted down with the help of the data inculcated from World Bank data. A graph here after will validate the increasing trend in the economic activity in Russia over time. 
India also has his place in the echelons of developing countries. In case of infrastructure for the India there had been major changes in their policies which bore fruit over time. India has put his might behind eye-catching project such as highways and urban transport (Sharma and Kushwaha, 2017). India has made a point of investing US 1.55 billion dollars on the infrastructure. Now, we are culminating as in the BRICS countries after moving through the studies of Brazil, Russia and India it is time we had taken into consideration the workings of China. Infrastructure in China is on the ebb as its population is increasing by the day. As for some data that creped in China has had an investment of around 323 billion dollars upon infrastructure (Dickovick and Eastwood, 2016). According to the World Bank, it is clear that the economic growths of India and China over certain time is showing increasing trends in their economic activities. Here below is the graph (Fig. 1) substantiate the points made aforementioned.

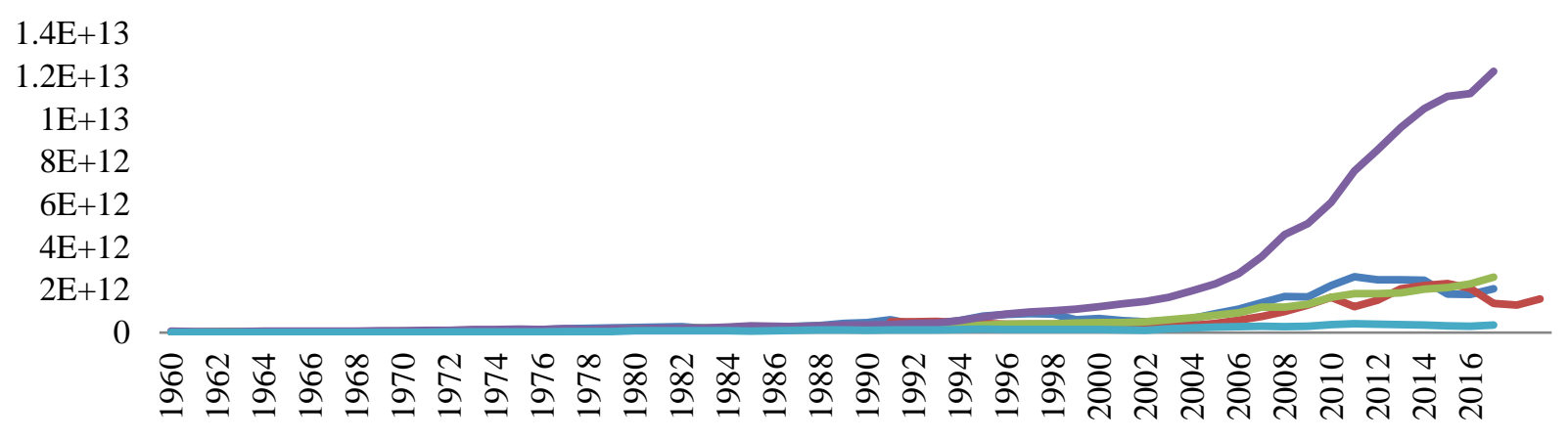

- GDP of Brazil $\longrightarrow$ GDP of Russia $\longrightarrow$ GDP of India $\longrightarrow$ GDP of China $\longrightarrow$ GDP of South Africa

Fig. 1. GDP of selected countries (USD)

Many studies have been conducted to put forth relationship between economic growth and infrastructure both, hard and soft. The studies were focused on relationships between concern variables as they ought to be. The studies were done for Asian and European countries, but none was conducted on BRICS studies and not many numerical figures were present on the surface. As put before, infrastructure is one of the pivotal rules to pass off the judgment on development. With proper infrastructure in place, the country brings in foreign investment in the shape of tourism and creates a void for the foreign business to create an investment. Infrastructure is akin to a wheel to keeps the economy on the roll. Infrastructure brings in employment, tourism and innovations in the play. This is much important when one compares the growth of a country with other.

The study has been put together because there lays a lacuna in the awareness what infrastructure can bring about in the country. The infrastructure of BRICS had been scrutinized in order to bring about a policy for other developing countries to take after. 
In recent years, BRICS countries have had a plethora of investment made on infrastructure. There is a dire need for developing countries to take on the menace of economic slowdown. BRICS countries put their money behind schools to create human capitals which is akin to creating future investments. Study investigated what had already been done on the BRICS case study. This research has been aimed at exploring the influence of infrastructural development on the economic growth of said nations. Causal relationship between infrastructural development and economic growth (EG) for selected nations was also quantified. Next section is going to explain further discussion of study such as data collection and its sources as well as an appropriate method on the base of integrated data.

\section{Methodology}

Data of selected variables for BRICS countries has been drawn out from year 1981 to 2016. The data has been inculcated from World Development Indicator (WDI). Two different models were used to see through this study. This study employed two models. In the first model, GDP growth per capita is a function of Gross Capital Formation (GCF), labor force participation (LFP), rail lines (RAIL), air transport freight (AIR), telephone lines (TEL), internet users (INTR) and mobile cellular subscriptions (MOB). Growth of GDP / capita is taken as proxy of EG of BRICS nations. GCF \& LFP are used as control variables, while, per capita energy consumption (ENER), per capita electricity use (ELEC), RAIL, AIR, INTR, TEL and MOB are the variables of transport and telecommunication infrastructure.

In this model, the combined collision of transport and telecommunication communications is checked on EG of BRICS. In the second model, growth of GDP per capita is function of GCF, LFP, ELEC and ENER. In this model growth of GDP/ capita has been taken as proxy of EG of BRICS. Here, GCF, LFP are used as control variables and ENER, ELEC are the variables of energy infrastructure. In this model, the impact of energy infrastructure is checked on economic growth of BRICS countries. We take all variables in log form except INTR and MOB. Similar methodology was used by Afzal et al. (2012) for their study of infrastructure and EG.

Impact of Infrastructure on EG. The general mathematical function for impact of infrastructure on EG is given below:

Economic growth $=\beta \mathrm{o}+\beta 1$ (transport infrastructure $)+\beta 2($ energy infrastructure $)+$ $\beta 3$ (telecommunication infrastructure) $+\mu \mathrm{i}$

Model takes into account telecommunication and transport infrastructure. Its econometric form is given below:

$$
\begin{gathered}
P G D P G R O W T H=\beta 0+\beta 1(L G C F)+\beta 2(L L F P)+\beta 3(R L A I L)+\beta 4(L A I R)+\beta 5(L T E L)+ \\
\quad \beta 6(I N T R)+\beta 6(M O B)+\mu
\end{gathered}
$$


The symbols used are defined below:

$\beta 0$ is the intercept and $\beta 1, \beta 2, \beta 3, \beta 4, \beta 5, \beta 6$ are the factors of coefficients.

$\mu$ is the error term.

PGDP $=$ Per Capita GDP growth (percentage)

$\mathrm{LGCF}=\log$ of gross capital formation (annual in current US \$)

LLFP $=\log$ of labor force participation (15+ year aged out of total population)

LRAIL $=\log$ of Rail lines (kilometer

LAIR $=\log$ of Air transport freight (million-ton kilometer)

LTEL $=\log$ of Telephone lines (/ 100 People)

LMBL $=\log$ of Mobile Cellular Subscriptions (/ 100 People)

LINTR $=\log$ of internet users (/100 people)

The Impact of Energy Infrastructure on EG. This model also takes into account energy infrastructure and econometric model is given below:

$P G D P$ growth $=\beta 0+\beta 1(L G C)+\beta 2(L L F P)+\beta 3(L P E N E R)+\beta 4(L P E L E C)+\mu i$

The symbols used are defined below:

PGDP $=$ Per Capita GDP growth (percentage)

$\mathrm{LGCF}=\log$ of gross capital formation (annual in current US \$)

LLFP $=\log$ of labor force participation ( +15 aged out of total population)

LELEC $=\log$ of per capita Electric Power Consumption (Kilowatt hour)

LENER $=\log$ of per capita Energy Use (Kg of Oil Equivalent)

This study used the various variables which have already been discussed in the above paragraph, such as GDP per Capita which was used by (Castelló and Doménech, 2002; Fedderke and Garlick, 2008; Hye and Lau, 2015), likewise variables GCF and other were used by previous studies like Borhan \& Ahmed, 2012; Al-Rawashdeh et al., 2015; Zaman et al., 2016).

Econometric Techniques. To estimate the relationship among concerned variables different econometric technique such as Generalized Methods of Moments (GMM), Vector Error Correction Model (VECM) as well as Autoregressive Distributed Lag (ARDL) model have been used in the literature. As GMM was used by Portugal-Perez \& Wilson (2012), similarly VECM model was used by Sahoo et al. (2012). An appropriate econometric technique was used on the basis of data stationery. If data is stationary at level as well as at the 1st difference, then ARDL model is oftenly used for the empirical estimation.

Borhan \& Ahmed (2012) used the same method for checking the correlation between infrastructure development and EG. First of all, stationarity of panel data was checked. For this purpose, Levin-Lin-Chu (LLC) and Im-Persaran-Shin (IPS) panel unit root test was used. The LLC test is like an Augmented Dicky Fuller test. This unit 
root test can be used for balanced panel data. Im, Pesaran, and Shin is the alternative of LLC unit root test. It is also a common unit root process. We have had checked through the stationarity from the unit root test to decide upon the results. Some of the results were stationary at level and some were stationary at first difference, it is why we have applied ARDL model. Granger Causality (GC) tests has been used to pull through the second part of study. This test is often called in to see through the causality among different variables regarding infrastructure (Zahra et.al, 2008).

This technique is used on the base of the predictions. According to GC, if a variable $X_{1}$ Granger impacts to another i.e. $X_{2}$ then it indicates that the previous values of $\mathrm{X}_{1}$ should help to forecast $\mathrm{X}_{2}$ on the base of the evidence regarding preceding values of second variable. This test is being used on a large scale over the last decade. In these arduous times GC is even more popular among economists as it is adept and sagacious. The mathematical form of GC is based on the linear Regression modeling of error term processes.

\section{Results and Discussions}

The following Table 1 presents the stationarity outcomes of IPS and LLC unit root tests. The findings of both unit root tests indicates that / capita GDP growth is significant with $1 \%$ level at $\mathrm{I}(0)$ both without and with trend. It is significant at $\mathrm{I}(1)$ that is the symptom of rejection of null hypothesis.

The results of both tests also shows that GCF, LFP, RAIL, AIR and ELEC are insignificant at $\mathrm{I}(0)$ but all these variables are highly significant at $\mathrm{I}(1)$ without trend and with trend at $1 \%$ level of significance. Moreover, the outcomes of IPS showed that INTR was not significant at $\mathrm{I}(0)$ rather it was significant at $\mathrm{I}(1)$ with $10 \%$ level of significance.

Findings of LLC test indicates that INTR is insignificant at both I(0) as well as $\mathrm{I}(1)$. The Table 1 also shows that MOB is insignificant at $\mathrm{I}(0)$ but it becomes significant at I(1)without trend and with trend at $10 \%$ level of significance. Findings of both tests also shows that the variable ENER is significant at I (1) with $1 \%$ level of significance but LLC outcomes displays that it is significant with 5\% level of significance only without trend.

In the last, the outcomes of IPS test for another variable telephone lines demonstrates that telephone lines is insignificant at $I(0)$ as well as $I(1)$ but the results of LLC test shows that telephone lines is highly significant at $\mathrm{I}(0)$ only without trend at $1 \%$ level of significance. Although, the overall outcomes of both tests shows that most variables are significant at I(1) but there are some other variables which are significant at $\mathrm{I}(0)$. 
Table 1. Findings of unit root tests

\begin{tabular}{|c|c|c|c|c|c|c|c|c|}
\hline \multicolumn{9}{|c|}{ Panel A: At level } \\
\hline \multicolumn{5}{|c|}{ IPS } & \multicolumn{4}{|c|}{ LLC } \\
\hline $\begin{array}{c}\text { Variable } \\
\text { s }\end{array}$ & Intercept & P-value & $\begin{array}{c}\text { Intercep } \\
\mathrm{t} \text { and } \\
\text { trend }\end{array}$ & P-value & Intercept & P-value & $\begin{array}{l}\text { Intercept } \\
\text { and trend }\end{array}$ & P-value \\
\hline PGDP & -3.60827 & $0.0002 *$ & -2.84274 & $0.0022 *$ & -3.25302 & $0.0006 *$ & -2.75176 & $0.0030 *$ \\
\hline LGCF & -1.75757 & 0.9606 & 0.49913 & 0.6912 & 0.19944 & 0.5790 & 0.49913 & 0.6481 \\
\hline LLFP & -0.69060 & 0.2449 & -1.38514 & 0.0830 & -0.76608 & 0.2218 & -1.08001 & 0.1401 \\
\hline LRAIL & 1.44825 & 0.9262 & 0.02218 & 0.5088 & 1.96949 & 0.8338 & 0.83979 & 0.7995 \\
\hline LAIR & 1.11112 & 0.8667 & 0.75352 & 0.7744 & 0.99727 & 0.1593 & 1.91053 & 0.9720 \\
\hline LTEL & -0.82807 & 0.2038 & 5.70195 & 1.0000 & -3.56539 & $0.0002 *$ & 2.20752 & 0.9864 \\
\hline LINTR & 4.14678 & 1.0000 & 2.34136 & 0.9904 & 2.08322 & 0.9814 & -1.54054 & $0.0617 * * *$ \\
\hline LMOB & 3.58495 & 0.9998 & 1.29405 & 0.9022 & 1.74027 & 0.9591 & -1.45654 & $0.0726 * * *$ \\
\hline LENR & 2.59966 & 0.9953 & 1.51162 & 0.98142 & 1.11810 & 0.8682 & 0.44676 & 0.6725 \\
\hline LELEC & -0.53517 & 0.2963 & -0.31593 & 0.3760 & -2.14942 & 0.0158 & -0.43257 & 0.3327 \\
\hline \multicolumn{9}{|c|}{ Panel B: $1^{\text {st }}$ difference } \\
\hline PGDP & -10.1993 & $0.0000 *$ & -9.24733 & $0.0000 *$ & -10.0584 & $0.0000 *$ & -9.24992 & $0.0000 *$ \\
\hline LGCF & -5.23403 & $0.0000 *$ & -3.74102 & 0.0001* & -4.70741 & 0.0000* & -3.85917 & $0.0001 *$ \\
\hline LLFP & -7.97921 & $0.0000 *$ & -6.60604 & 0.0000* & -7.22970 & 0.0000* & -5.90660 & $0.0000 *$ \\
\hline LRAIL & -8.29825 & 0.0000* & -7.15904 & 0.0000* & -6.47000 & 0.0000* & -5.46044 & $0.0000 *$ \\
\hline LAIR & 7.80422 & 0.0000* & -9.02323 & 0.0000* & -3.27030 & 0.0005* & -2.26692 & $0.0117 *$ \\
\hline LTEL & -38869 & 0.6512 & -1.11921 & 0.1315 & 1.14723 & 0.8744 & -0.85126 & 0.1973 \\
\hline LINTR & -1.37910 & $0.0839 * * *$ & -1.07646 & 0.1409 & -0.70905 & 0.2391 & 1.67321 & 0.9529 \\
\hline LMOB & -1.45789 & $0.0724 * * *$ & -1.51047 & $0.0655 * * *$ & -1.55346 & $0.0602 * * * *$ & -1.80344 & $0.0357 * *$ \\
\hline LENR & -1.4578 & $0.0000 *$ & -2.41372 & 0.0079* & -2.04437 & $0.0205 * *$ & -0.68097 & 0.2479 \\
\hline LELEC & -0.35606 & $0.0002 *$ & -2.58329 & $0.0049 *$ & -2.68841 & $0.0036 *$ & -2.31269 & $0.0104 *$ \\
\hline
\end{tabular}

$*, * *, * * *$ significance level at 1,5 \& 10 percent

The following Table 2 indicates the long run results of ARDL model for equation (1). The results of ARDL model shows that GCF has negative but highly significant impact on per capita GDP growth. Several variables included in the equation (1) as LFP, RAIL, TEL, INTR and MOB have positive as well as highly significant impact on the per capita GDP growth of BRICS countries.

The results of mobile cellular subscriptions (MOB) are also consistent with the study of Patra and Acharya (2011). In the same way, the results of labor force participation (LFP) are also supported by the study Sahoo et al. (2010). Other variables also showed positive and significant influence on dependent variable. The variable of AIR has positive but insignificant impact on / capita GDP growth of BRICS countries and these results were consistent with the results of Hong et al. (2011). 
Table 2. Long run ARDL findings for Model 1

\begin{tabular}{|c|c|c|c|c|}
\hline Variables & Coefficient & Std. Error & T-statistics & Prob. \\
\hline LGCF & -50.59243 & 2.354422 & -21.48826 & $\mathbf{0 . 0 0 0 0} *$ \\
\hline LLFP & 117.2068 & 4.723079 & 24.81576 & $\mathbf{0 . 0 0 0 0} *$ \\
\hline LRAIL & 213.2254 & 37.59881 & 5.671069 & $\mathbf{0 . 0 0 0}^{*}$ \\
\hline LAIR & 1.357988 & 1.356096 & 1.001395 & 0.3212 \\
\hline LTEL & 4.792412 & 0.868794 & 5.516164 & $\mathbf{0 . 0 0 0 0} *$ \\
\hline INTR & 0.488466 & 0.033280 & 14.67731 & $\mathbf{0 . 0 0 0 0} *$ \\
\hline MOB & 0.154474 & 0.021751 & 7.101850 & $\mathbf{0 . 0 0 0 0}^{*}$ \\
\hline
\end{tabular}

* indicate significance level at $1 \%$

The estimation of the model with variable convergence rates show that GCF, LFP, RAIL, AIR, INTR, TEL and MOB can play significant part in annually convergence of model from short run to long run. The value of Cointe is negative as well as significant, that is indicating that the model will converge from short run to long run annually with a speed of $0.536036 \%$ (see Table 3 ).

Table 3. Short run ARDL results

\begin{tabular}{|c|c|c|c|c|}
\hline Variables & Coefficient & Std. Error & T-statistics & Prob. \\
\hline COINTEQ01 & -0.536036 & 0.262532 & -2.041798 & $\mathbf{0 . 0 4 6 2} * *$ \\
\hline D(LGCF) & 25.98713 & 8.215039 & 3.163361 & $0.0026^{*}$ \\
\hline D(LLFP) & -18.56803 & 30.57927 & -0.607210 & 0.5463 \\
\hline D(LRAIL) & -292.2913 & 234.1195 & -1.248471 & 0.2173 \\
\hline D(LAIR) & 21.13223 & 9.583367 & 2.205094 & $0.0318^{* *}$ \\
\hline D(LTEL) & 24.33580 & 28.24893 & 0.861477 & 0.3929 \\
\hline D(INTR) & 0.069327 & 0.294890 & 0.235094 & 0.8150 \\
\hline D(MOB) & 0.292642 & 0.121322 & 2.412117 & $0.0194^{*}$ \\
\hline C & -344.1147 & 171.9701 & -2.001014 & $0.0505^{* *}$ \\
\hline
\end{tabular}

The Table 4 presents the results of Pairwise GC test for equation (1). The result of first row of Table 3 displays the bidirectional causality between LFP and per capita GDP growth because p-values of both that are significant with $5 \%$ level of significance. Null hypothesis can be rejected, and we can accept the alternative hypothesis about the existence of bidirectional causal relationship. In the same way, the results of Table 3 also show that there is bidirectional causality among MOB and GCF, INTR and TEL, and, MOB and TEL.

Likewise, the results of Table 4 also report the existence of unidirectional causal relationships among many variables as; MOB and INTR, per capita GDP growth and MOB, per capita GDP growth and INTR, INTR and GCF, INTR and LFP, AIR and LFP, and unidirectional causality also exists between AIR and per capita GDP growth. Although, there exists a causal relationship among several variables related to infrastructure, but among all these variables, there are also some variables that have no causal relationships with the other variables. 
Table 4. Granger causality results

\begin{tabular}{|c|c|c|c|c|c|}
\hline Null hypothesis & F. Statistic & Prob. & Null hypothesis & F. Statistic & Prob. \\
\hline LLFP $\rightarrow$ PGDP & 4.06676 & 0.0189* & LTEL $\rightarrow$ LGCF. & 0.16534 & 0.8477 \\
\hline PGDP $\rightarrow$ LLFP. & 3.72218 & $0.0262 * *$ & LGCF $\rightarrow$ LTEL. & 1.47451 & 0.2319 \\
\hline LGCF $\rightarrow$ PGDP & 11.4368 & 2.1105 & LAIR $\rightarrow$ LGCF. & 1.50952 & 0.2241 \\
\hline PGDP $\rightarrow$ LGCF. & 8.74513 & $0.0002 *$ & LGCF $\rightarrow$ LAIR. & 2.35764 & 0.978 \\
\hline LRAIL $\rightarrow$ PGDP & 0.55237 & 0.5766 & INTR $\rightarrow$ LGCF. & 4.03072 & 0.0195* \\
\hline PGDP $\rightarrow$ LRAIL. & 0.46419 & 0.6295 & LGCF $\rightarrow$ INTR. & 0.87043 & 0.4207 \\
\hline LTEL $\rightarrow$ PGDP & 1.13502 & 0.3239 & $\mathrm{MBL} \rightarrow$ LGCF & 3.34224 & $0.0378 * *$ \\
\hline PGDP $\rightarrow$ LTEL. & 0.70273 & 0.4967 & LGCF $\rightarrow$ MBL. & 3.01892 & $0.0516 * *$ \\
\hline LAIR $\rightarrow$ PGDP & 0.09006 & 0.9141 & LTEL $\rightarrow$ LRAIL. & 1.27200 & 0.2830 \\
\hline PGDP $\rightarrow$ LAIR. & 3.35651 & $\mathbf{0 . 0 3 7 3 * *}$ & LRAIL $\rightarrow$ LTEL. & 0.56881 & 0.5673 \\
\hline INTR $\rightarrow$ PGDP & 2.07526 & 0.1288 & LAIR $\rightarrow$ LRAIL. & 0.59927 & 0.5504 \\
\hline PGDP $\rightarrow$ INTR. & 2.62620 & $0.0754 * * *$ & LRAIL $\rightarrow$ LAIR. & 1.30672 & 0.2735 \\
\hline $\mathrm{MBL} \rightarrow \mathrm{PGDP}$ & 1.49470 & 0.2273 & INTR $\rightarrow$ LRAIL. & 0.07347 & 0.9292 \\
\hline PGDP $\rightarrow$ MBL. & 2.54452 & $0.0816 * * *$ & LRAIL $\rightarrow$ INTR. & 0.08362 & 0.9198 \\
\hline LGCF $\rightarrow$ LLFP. & 0.40668 & 0.6665 & MBL $\rightarrow$ LRAIL. & 0.03201 & 0.9685 \\
\hline LLFP $\rightarrow$ LGCF. & 1.44105 & 0.2396 & LRAIL $\rightarrow$ MBL. & 0.34717 & 0.7072 \\
\hline LRAIL $\rightarrow$ LLFP. & 0.48892 & 0.6142 & LAIR $\rightarrow$ LTEL. & 0.11089 & 0.8951 \\
\hline LLFP $\rightarrow$ LRAIL & 0.55330 & 0.5761 & LTEL $\rightarrow$ LAIR. & 0.74546 & 0.4761 \\
\hline LTEL $\rightarrow$ LLFP. & 0.11766 & 0.8891 & INTR $\rightarrow$ LTEL. & 2.54344 & $0.0817 * * *$ \\
\hline LLFP $\rightarrow$ LTEL & 0.01598 & 0.9841 & LTEL $\rightarrow$ INTR. & 3.66888 & $0.0276 * *$ \\
\hline LAIR $\rightarrow$ LLFP. & 0.17585 & 0.8389 & MBL $\rightarrow$ LTEL. & 3.16618 & $0.0447 * *$ \\
\hline LLFP $\rightarrow$ LAIR & 6.02158 & $0.0030^{*}$ & LTEL $\rightarrow$ MBL. & 3.35249 & $0.0374 * *$ \\
\hline LINTR $\rightarrow$ LLFP. & 0.93058 & 0.3964 & INTR $\rightarrow$ LAIR. & 0.64765 & 0.5246 \\
\hline LLFP $\rightarrow$ INTR & 4.99526 & $0.0078^{*}$ & LAIR $\rightarrow$ INTR. & 1.98757 & 0.1403 \\
\hline MBL $\rightarrow$ LLFP. & 1.17367 & 0.3118 & MBL $\rightarrow$ LAIR. & 0.67271 & 0.5117 \\
\hline LLFP $\rightarrow$ MBL. & 0.05636 & 0.9452 & LAIR $\rightarrow$ MBL. & 1.15613 & 0.3172 \\
\hline LRAIL $\rightarrow$ LGCF. & 0.47101 & 0.6252 & $\mathrm{MBL} \rightarrow$ INTR. & 15.8934 & 5.007 \\
\hline LGCF $\rightarrow$ LRAIL. & 1.31331 & 0.2717 & $\mathrm{INTR} \rightarrow \mathrm{MBL}$ & 3.25063 & $0.0412 * *$ \\
\hline
\end{tabular}

$*, * *, * * *$ significance level at $1,5 \& 10$ percent

The Table 5 shows the long run results of ARDL model for the equation (2). GCF has positive but insignificant impact on per capita GDP growth of BRICS countries. An increase in the GCF leads to increase in the economic growth in BRICS countries. Likewise, this table revealed that LFP and ELEC have significant and positive impacts on EG. As LFP increases, it could lead to an increase in the EG for the selected countries. In the same way, as ELEC increases, the economic growth in BRICS countries also increases. These results are consistent with the study of Patra and Acharya (2011). On the other hand, variable ENER has significant but negative impact on / capita GDP growth.

Table 5. Long run ARDL results

\begin{tabular}{|c|c|c|c|c|}
\hline Variables & Coefficient & Std. Error & T- statistics & Prob. \\
\hline LGCF & 0.233109 & 1.967587 & 0.118475 & 0.9059 \\
\hline LLFP & 11.33359 & 4.820231 & 2.351235 & $\mathbf{0 . 0 2 0 8} * *$ \\
\hline LENR & -19.18279 & 8.488140 & -2.259952 & $\mathbf{0 . 0 2 6 1} * *$ \\
\hline LELEC & 12.28814 & 3.428154 & 3.584479 & $\mathbf{0 . 0 0 0 5} *$ \\
\hline
\end{tabular}

*,**, indicate significance level at $1 \%$ and $5 \%$ respectively 
Table 6 shows the short run ARDL results for equation (2) which shows that value of cointeq01 is negative and also significant at $1 \%$ level of significance. The short-run outcomes show that the model will converge annually from short run to long run with a speed of $0.674133 \%$ with the change in GCF, LFP, ENER and ELEC.

Table 6. Short run ARDL results

\begin{tabular}{|c|c|c|c|c|}
\hline Variables & Coefficient & Std. Error & T- statistics & Prob. \\
\hline COINTEQ01 & -0.674133 & 0.262799 & -2.565209 & $\mathbf{0 . 0 1 1 9} *$ \\
\hline D(LGCF) & 15.38956 & 3.101990 & 4.961188 & $0.0000^{*}$ \\
\hline D(LLFP) & -4.022663 & 15.02317 & -0.267764 & 0.7895 \\
\hline D(LENR) & 17.41514 & 23.09409 & 0.754095 & 0.4526 \\
\hline DLELEC) & 70.82397 & 43.29502 & 1.635846 & 0.1051 \\
\hline C & 3.044188 & 0.982768 & 3.097566 & $0.0026^{*}$ \\
\hline
\end{tabular}

The Table 7 shows the results of pairwise Granger Causality test for equation (2). The results of Table 6 shows that bidirectional causal relationship only exists between LFP and Per capita GDP growth, and p-values for these both variables are significant at the level of 5\%. In the same way, there exists unidirectional causal relationship among many other variables as; GCF and per capita GDP growth, GCF and LFP, GCF and ELEC and as well as unidirectional causality also exists between GCF and ENER. In contrast, among these variables there are some other variables that have no causal relationship with each other as per capita GDP growth and ENER, per capita GDP growth and ELEC, ELEC and LFP, ENER and LFP. There is no existence of causality between ENER and ELEC.

Table 7. Granger causality results

\begin{tabular}{|c|c|c|c|c|c|}
\hline Null hypothesis & F. Statistic & Prob. & Null hypothesis & F. Statistic & Prob. \\
\hline LLFP $\rightarrow$ PGDP & 4.06676 & $\mathbf{0 . 0 1 8 9} *$ & LELEC $\rightarrow$ LGCF. & 2.07526 & 0.1288 \\
PGDP $\rightarrow$ LLFP. & 3.72218 & $\mathbf{0 . 0 2 6 2} * *$ & LGCF $\rightarrow$ LELEC. & 2.62620 & $\mathbf{0 . 0 7 5 4} * * *$ \\
\hline LGCF $\rightarrow$ PGDP & 11.4368 & 2.1105 & LENR $\rightarrow$ LGCF. & 1.49470 & 0.2273 \\
PGDP $\rightarrow$ LGCF. & 8.74513 & $\mathbf{0 . 0 0 0 2} *$ & LGCF $\rightarrow$ LENR. & 2.54452 & $\mathbf{0 . 0 8 1 6 * * *}$ \\
\hline LELEC $\rightarrow$ PGDP & 0.55237 & 0.5766 & LELEC $\rightarrow$ LLFP. & 0.40668 & 0.6665 \\
PGDP $\rightarrow$ LELEC. & 0.46419 & 0.6295 & LLFP $\rightarrow$ LELEC. & 1.44105 & 0.2396 \\
\hline LENR $\rightarrow$ PGDP & 1.13502 & 0.3239 & LENR $\rightarrow$ LLFP. & 0.48892 & 0.6142 \\
PGDP $\rightarrow$ LENR. & 0.70273 & 0.4967 & LLFP $\rightarrow$ LENR. & 0.55330 & 0.5761 \\
\hline LLFP $\rightarrow$ LGCF. & 0.09006 & 0.9141 & LENR $\rightarrow$ LELEC. & 0.11766 & 0.8891 \\
LGCF $\rightarrow$ LLFP. & 3.35651 & $\mathbf{0 . 0 3 7 3} *$ & LELEC $\rightarrow$ LENR. & 0.01598 & 0.9841 \\
\hline
\end{tabular}

$*, * *, * * *$ significance level at $1,5 \& 10$ percent

\section{CONCLUSION}

In this study, we got into the profundity of the investigation by keeping some variables in control such as GCFn and LFP. After getting through this study, it can be said with certainty that infrastructure has had a positive impact on BRIC economies. Our results are in cahoots with other studies that had been done on the same whim 
(Coulibaly 2013). The results have shown that in the economic growth of BRICS capital formulation, transport infrastructure, telecommunication infrastructure are playing a pivotal role. Infrastructure development brings about a positive change in the economic growth of BRICS countries.

We have done out best to include all of the characteristics which may be imperative for our investigation, all of the issues has been discussed which are related to the problem of the study in hand. The findings both from theoretical as well as empirical analysis confirm optimistic relation between dependent and independent variables. Albeit the conclusion withdrawn from this study is if BRICS countries want to further enhance their economic growth and development, they will have to further put their might behind infrastructure development.

Aforementioned were the pros of this study. But this research is as same as any other with both the pros and cons. The pivotal con of this study is the limitations that came into play. The infrastructure quality is not estimated in the model. Second to this, there was a paucity of the data on social infrastructure sectors as irrigation sector, health and education. There was also a dearth of the data on physical infrastructure, financial institutions like banks.

\section{References}

Afzal, M., Malik, M. E., Begum, I., Sarwar, K., Fatima, H. (2012). Relationship among education, poverty and economic growth in Pakistan: an econometric analysis // Journal of Elementary Education. No. 22(1): 23-45.

Al-Rawashdeh, R., Jaradat, A. Q., Al-Shboul, M. (2015). Air pollution and economic growth in MENA countries: Testing EKC hypothesis. // Environmental Research, Engineering and Management. No. 70(4): 54-65.

Asteriou, D. and G. M. Agiomirgianakis. (2001). Human capital and economic growth: time series evidence from Greece // Journal of Policy Modeling. No. 23(5): 481-489.

Bassanini, A., Scarpetta, S., Visco, I. (2000). Knowledge technology and economic growth: recent evidence from OECD countries National Bank of Belgium Working Paper (6). // http://dx.doi.org/10.2139/ssrn.1705109

Borhan, H. B., Ahmed, E.M. (2012). Simultaneous Model of Pollution and Income in Malaysia // International Journal of Economic Perspectives. No. 6(1): 53-74.

Brown, D., Fay, M., Lall, S. V., Wang, H. G., Felkner, J. (2008). Death of distance? Economic implications of infrastructure improvement in Russia // EIB Papers. No. 13(2): 126-148.

Castelló, A., Doménech, R. (2002). Human capital inequality and economic growth: some new evidence // The Economic Journal. No. 112: C187-C200.

Coulibaly, S. (2013). Rethinking the form and function of cities in post-Soviet countries. The World Bank. // https://elibrary.worldbank.org/doi/abs/10.1596/1813-9450-6292

Czernich, N., Falck, O., Kretschmer, T., Woessmann, L. (2011). Broadband infrastructure and economic growth // The Economic Journal. No. 121(552): 505-532.

Dickovick, J.T., Eastwood, J. (2016). Comparative Politics: Integrating Theories, Methods, and Cases, Oxford University Press.

Esfahani, H.S., Ramírez, M.A.T. (2003). Institutions, infrastructure, and economic growth // Journal of development Economics. No. 70(2): 443-477. 


\section{Bilal Hussain, Seyd Asif Ali Naqvi, Muhammad Sohail Amjad Makhdum, Syed Ale Raza Shah Influence of Infrastructure Development on Economic Growth BRICS Countries}

Fedderke, J., Garlick, R. (2008). Infrastructure development and economic growth in South Africa: A review of the accumulated evidence // Policy Paper (12): 1-28.

Hong, J., Chu, Z., Wang, Q. (2011). Transport infrastructure and regional economic growth: evidence from China // Transportation. No. 38(5): 737-752.

Hye, Q.M.A., Lau, W.Y. (2015). Trade openness and economic growth: empirical evidence from India // Journal of Business Economics and Management. No. 16(1): 188-205.

Laursen, K. (2000). Trade specialisation, technology and economic growth // Books. https://www.eelgar.com/

Marcilio, I., Gouveia N. (2007). Quantifying the impact of air pollution on the urban population of Brazil // Cadernos De Saude Publica. 23: S529-S536.

Narayan, P.K., Narayan, S. (2013). The short-run relationship between the financial system and economic growth: New evidence from regional panels // International Review of Financial Analysis. No. 29: 70-78.

Peters, J. (2008). Labour market deregulation and the decline of labour power in North America and Western Europe // Policy and Society. No. 27(1): 83-98.

Porter, M. E. (2000). Location, competition, and economic development: Local clusters in a global economy // Economic Development Quarterly. No. 14(1): 15-34.

Patra, A. K., Acharya, A. (2011). Regional disparity, infrastructure development and economic growth: An inter-state analysis // Research and Practice in Social Sciences. No. 6(2): 17-30.

Portugal-Perez, A., Wilson, J.S. (2012). Export performance and trade facilitation reform: Hard and soft infrastructure // World Development. No. 40(7): 1295-1307.

Rodriguez, F. Rodrik, D. (2000). Trade policy and economic growth: a skeptic's guide to the crossnational evidence // NBER Macroeconomics Annual. No. 15: 261-325.

Sharma, N.K., Kushwaha, G.S. (2017). A Study on Indian Logistics Network and Its Impact on Economic Growth // IUP Journal of Supply Chain Management. No. 14(4): 38-60.

Smulders, S., De Nooij, M. (2003). The impact of energy conservation on technology and economic growth // Resource and Energy Economics. No. 25(1): 59-79.

Sridhar, K. Sridhar, V. (2008). Telecommunications infrastructure and economic growth: Evidence from developing countries // Applied Econometrics and International Development. No. 7(2): 25-35. Sahoo, P., Dash, R. K., Nataraj, G. (2010). Infrastructure development and economic growth in China // Institute of Developing Economies. Discussion Paper 261.

Wei, C. (2008). The role of human capital in China's economic development: Review and new evidence// China Economic Review.No. 19(3): 421-436.

Zaman, K., bin Abdullah, A., Khan, A., bin Mohd Nasir, M. R., Hamzah, T. A. A. T., Hussain, S. (2016). Dynamic linkages among energy consumption, environment, health and wealth in BRICS countries: green growth key to sustainable development // Renewable and Sustainable Energy Reviews. No. 56: 1263-1271. 


\title{
SUPPLEMENTARY FILE
}

Table S8: Short run ARDL results of equation 1

\begin{tabular}{|c|c|c|c|c|}
\hline Variables & Coefficient & Std. Error & T- statistics & Prob. \\
\hline COINTEQ01 & -0.536036 & 0.262532 & -2.041798 & $\mathbf{0 . 0 4 6 2 * *}$ \\
\hline D(LGCF) & 25.98713 & 8.215039 & 3.163361 & $0.0026^{*}$ \\
\hline D(LLFP) & -18.56803 & 30.57927 & -0.607210 & 0.5463 \\
\hline D(LRAIL) & -292.2913 & 234.1195 & -1.248471 & 0.2173 \\
\hline D(LAIR) & 21.13223 & 9.583367 & 2.205094 & $0.0318^{* *}$ \\
\hline D(LTEL) & 24.33580 & 28.24893 & 0.861477 & 0.3929 \\
\hline D(INTR) & 0.069327 & 0.294890 & 0.235094 & 0.8150 \\
\hline D(MOB) & 0.292642 & 0.121322 & 2.412117 & $0.0194^{*}$ \\
\hline C & -344.1147 & 171.9701 & -2.001014 & $0.0505^{* *}$ \\
\hline
\end{tabular}

$*, * *$, indicate significance level at $1 \%$ and $5 \%$ respectively.

Table S9: Short run ARDL results of equation 2

\begin{tabular}{|c|c|c|c|c|}
\hline Variables & Coefficient & Std. Error & T- statistics & Prob. \\
\hline COINTEQ01 & -0.674133 & 0.262799 & -2.565209 & $0.0119 *$ \\
\hline D(LGCF) & 15.38956 & 3.101990 & 4.961188 & $0.0000^{*}$ \\
\hline D(LLFP) & -4.022663 & 15.02317 & -0.267764 & 0.7895 \\
\hline D(LENR) & 17.41514 & 23.09409 & 0.754095 & 0.4526 \\
\hline DLELEC) & 70.82397 & 43.29502 & 1.635846 & $0.0026^{*}$ \\
\hline C & 3.044188 & 0.982768 & 3.097566 & \\
\hline
\end{tabular}

* indicate significance level at $1 \%$.

\section{INFRASTRUKTŪROS VYSTYMOSI POVEIKIS BRICS ŠALYSE}

\author{
Bilal Hussain*, Syed Asif Ali Naqvi *, Muhammad Sohail Amjad Makhdum*, \\ Syed Ale Raza Shah* \\ "Ekonomikos Katedra, Vyriausybès koledžo universitetas Faisalabad, Pakistanas
}

Gauta 201903 14; priimta 20190902

Šiame dokumente buvo įvertintas infrastruktūros poveikis BRICS šaliu ekonominim augimui. Taip pat išanalizuoti priežastiniai ryšiai tarp infrastruktūros plètros ir ekonominio augimo. Šiam tikslui pasiekti buvo naudojami du skirtingi modeliai bei naudoti 1981-2016 metu duomenys. Analizei atlikti buvo pritaikytas ARDL modelis. Šio tyrimo išvados parodè, kad transporto ir telekomunikacijų infrastruktūra daro teigiamą poveikį ekonomikos augimui, palyginti su energetikos infrastruktūra. Tyrimo rezultatai atskleidè, kad būtina sukurti politiką, kuri pagerintų fizinę ir socialinę infrastruktūrą. Šiais naujais laikais, kai technologijos rodo pavyzdi, ypatingas dèmesys turètų būti skiriamas telekomunikacijų infrastruktūrai.

Raktiniai žodžiai: ekonomikos augimas; infrastruktūra; plètra;telekomunikacijos.

JEL kodai: O00, P48, R11 